English Language and Linguistics 23.3: 671-699. (C) Cambridge University Press 2018. This is an Open Access article, distributed under the terms of the Creative Commons Attribution licence (http://creativecommons.org/licenses/by/4.0/), which permits unrestricted re-use, distribution, and reproduction in any medium, provided the original work is properly cited. doi:10.1017/S1360674318000059

\title{
A construction of independent means: the history of the Way construction revisited ${ }^{1}$
}

\author{
TERESA FANEGO \\ University of Santiago de Compostela
}

(Received 24 November 2017; revised 3 March 2018)

\begin{abstract}
The emergence and development of the Way construction was famously examined by Israel (1996) in a study which traced the modern form of the construction to three senses or subschemas, namely manner of motion (He stumbled his way to the front door), means of motion (He dug his way out of the prison) and incidental activity (He whistled his way out of the room). The present article moves beyond the late Middle English period - the starting point of Israel's research - and looks at the precursors of the Way construction since Old English times, as well as its interaction with the Intransitive Motion construction (IMC) (He walked into the room). By approaching the data in terms of Goldberg's typology (1997) of verb-construction relationships, which is finer-grained than Israel's tripartite division, the analysis identifies the areas of conceptual and constructional overlap that have existed between the Way construction and the IMC in the course of history, and shows that the Way construction has gradually specialised in the expression of those relations which could not be readily coded in the IMC, such as means of motion and incidental activity. The study thus seeks to contribute to a better understanding of how the constructicon, the repertory of constructions making up the grammar of a language, may change over time.
\end{abstract}

Keywords: Way construction, Intransitive Motion construction, networks, force dynamics, British and American English

\section{Introduction}

The label WAY CONSTRUCTION, coined by Jackendoff (1990: 211), is applied in the literature to strings such as those in (1), consisting of a verb, the lexical element way preceded by a possessive determiner coreferential with the subject, and a directional phrase.

(1) $\mathrm{SUBJ}_{\mathrm{i}} \mathrm{V}\left[\mathrm{POSS}_{\mathrm{i}}\right.$ way $] \mathrm{OBL}_{\text {directional }}$

(a) The novice skier walked her way down the ski slope. (Goldberg 1995: 205)

(b) Frank dug his way out of the prison. (Goldberg 1995: 199)

(c) Frank found his way to New York. (Goldberg 1995: 199)

In all of these examples, the implication is that the subject referent moves along a path towards a specified goal. Yet as Goldberg noted in her seminal analysis of the Way

1 For generous financial support I am grateful to the Spanish Ministry of Economy, Industry and Competitiveness (grant FFI2017-86884-P) and the Regional Government of Galicia (grants ED431B 2017/12 and ED431D 2017/09). Thanks are also due to Laurel J. Brinton and two anonymous reviewers for their most valuable suggestions on an earlier draft. 
construction, 'the construction's semantics cannot be fully predicted on the basis of [its] constituent parts' (1995: 199): though the verb walk in (1a) above is indeed a verb of motion, dig and find in $(1 \mathrm{~b}-\mathrm{c})$ are not, which shows that the motion interpretation has to be attributed not to the verb but 'directly to the construction itself' (1995: 201) as a conventional form-meaning pairing, that is, a CONSTRUCTION in the sense of Construction Grammar (CxG) (Fillmore et al. 1988; Goldberg 1995, among many others).

Over the past three decades, the syntactic and semantic properties of the Way construction in Present-day English (PDE) have proved to be a favourite topic of discussion. The historical development of the construction has also received considerable attention, initially by Israel (1996), who examined its emergence from late Middle English (ME) times; more recently by Traugott \& Trousdale (2013: 7691), who reinterpret Israel's findings from the perspective of Diachronic Construction Grammar (Traugott \& Trousdale 2013; Barðdal \& Gildea 2015). Another notable study, also diachronic in orientation, is Perek (2016); this provides the first quantitative, corpus-based analysis of the construction to date, based on data extracted from the Corpus of Historical American English (COHA; Davies 2010-).

Building on the insights offered by these various publications, the present article addresses the Way construction with a twofold aim: (i) on the one hand, to attempt to provide answers to aspects of its history and chronology which are still in need of clarification, as expounded in section 2 below; (ii) on the other, to examine the connections between the observed changes in the Way construction over the course of time and the changes that have affected another major motion construction of English, the Intransitive Motion construction (IMC), as illustrated in the Old English (OE) example in (2) below. As is well known, $\mathrm{CxG}$ sees the grammar of a language as a structured inventory of constructions, a CONSTRUCTICON, but so far the diachronic implications of that conception remain an under-researched area (though see here Traugott \& Trousdale 2013: chapter 2). This article seeks to contribute to a better understanding of the role of constructional networks by examining the interrelated developments of two English constructions encoding intransitive motion.

(2) SUBJ V OBL directional

pæt wif ... efste to ðære byrig

'the woman ... hurried to the city' (ÆCHom 5 214; DOE ef(e)stan v. A.1.a)

The remainder of the article is organised as follows. Section 2 reviews the diachronic analyses of the Way construction mentioned in the previous paragraphs and points to the issues they have left unanswered. Section 3 describes the data sources and the procedure for data collection on the Way construction in earlier stages of English. Section 4.1 outlines the theoretical background, in particular Goldberg's typology (1997) of verb-construction relationships. This typology is then applied in section 4.2 to the analysis of the earlier history of the IMC and in section 5 to the analysis of the precursors of the Way construction. Section 6 offers a detailed quantitative analysis of the development of the Way construction from 1700 onwards, in both British and American English. Section 7 summarises the main findings. 
2 Earlier research on the Way construction

\subsection{Israel (1996)}

The Way construction was famously chosen by Adele Goldberg (1995) as one of four English patterns which she used to argue for a conception of grammar consisting of an interrelated network of constructions. Her analysis was supplemented shortly afterwards by Israel's influential study (1996), where he applied the principles of CxG to an examination of how the Way construction emerged and developed since ME times. Based on the $O E D$ on CD-ROM and contemporary examples from the Oxford University Press corpus, Israel argues that the modern Way construction can be traced back to three early usages or threads, as detailed below, in which possessed nouns such as ME wei 'way', ride or strete 'street' 'appeared in direct object position with verbs of motion [and] path creation' (1996: 221), as in ME wente he his ride. Examples with $w e i$ 'constitute a special case of this more general construction and are common from at least 1350 on' (1996: 221), forming the basis for subsequent analogical extensions to a wide range of verbs:

(i) The manner thread; this involves verbs 'featur[ing] high-frequency motion verbs like go, ride, run, pursue, wend and pass' (Israel 1996: 221) and is the earliest subschema. From the seventeenth century onwards, according to Israel, the construction gradually expands 'as verbs coding path shape, rate, and manner of motion ... find their way into usage by analogy with the more basic motion verbs already established in the construction' (1996: 221-2).

(3) From Samos have I wing'd my way. (1667 Congreve) $)^{2}$

(ii) The means thread; this is recorded from the end of the sixteenth century (1996: 223) and involves verbs of path clearing like cut, plug, dig, clear, etc.

(4) through the raine Of the wide ayre her way does cut amaine. (1590 Spenser)

(iii) The incidental activity thread develops by the mid nineteenth century and involves verbs that code 'neither a means nor a manner of motion, but rather some incidental activity that happens to accompany motion' (1996: 224). According to Israel, until well into the twentieth century instances of this sort consistently involve sounds produced in the process of moving:

(5) He ... whistled his way to the main front-door. (1866 Blackmore)

Israel's analysis, which is arguably the first to have examined a set of historical changes from a $\mathrm{CxG}$ perspective, has proved immensely influential. Yet the tripartite semantic classification he proposes, as discussed at greater length in the remainder of this article, cannot adequately account for the complexities of the Way construction, whether in earlier English or in PDE. A second problem is that much of Israel's

2 Examples (3)-(5) are Israel's (1996). 
discussion relates not to the Way construction as we understand it today, but rather to one of its precursors, namely a motion construction with way in the object slot but without directional phrase, as in his example The kyng ... wente his way (1412, Hoccleve). As a result, it is often not clear whether Israel's claims are meant to apply only to this simpler, shorter construction, or also to the Way construction proper, as when he points out (1996: 221) that 'up to 1700 only sixteen verb types are attested in the [manner] thread'; this figure, in light of the quantitative evidence presented below (see in particular tables 5 and 6), seems unrealistic.

Finally, Israel's chronology of the changes is also somewhat uncertain. From his account, it would appear that what he calls the manner thread is the earliest subschema, yet the first example of the manner thread that he adduces which fully conforms to the characteristics of the contemporary Way construction is (3) above, which dates from 1667 and is thus later than his first example (1590) of the means thread, quoted above as (4).

\subsection{Traugott \& Trousdale (2013)}

Traugott \& Trousdale's more recent approach (2013) to the Way construction builds largely on Israel's account (1996). On the basis of a qualitative analysis of examples from the Middle English Dictionary (MED; Kurath et al. 1952-2001) and other historical sources, Traugott \& Trousdale argue that the modern Way construction arose out of 'two distinct sets of precursors with ME wei: an intransitive motion set, and a transitive set' (2013: 79). The intransitive set is attested with verbs like go, fare, flee, wend and ride, the latter with transitives, 'mainly the acquisition verbs nim- "take", take' (2013: 80).

In the Early Modern English period there is evidence, according to Traugott \& Trousdale, that 'the transitive set was being expanded ... with take ... as the prototype. There is construction-type (host-class) expansion of POSS way to new verbs including make, and pave, sometimes with non-animate subjects' (2013: 84). (6) is an example of this new transitive usage:

(6) the Fire ... made its way to St. Giovanni di Galermo (1669 Winchilsea)

On the basis of this and analogous examples, Traugott \& Trousdale conclude that by the end of the seventeenth century a Way construction with transitive verbs had arisen: '[a] number of new verbs meaning "creating a path" are attested at this time. The pathcreation is often achieved by some specific means, e.g. fight, battle, force, push, drag, and often in the face of some obstruction or opposition' (2013: 84-5).

Overall, Traugott \& Trousdale's qualitative analysis usefully identifies the historical links of the Way construction with both the transitive and intransitive constructions. Yet, like Israel before them, their coverage of the construction is limited, since it starts basically from late ME times and thus overlooks the fact that precursors of the Way construction are attested already in $\mathrm{OE}$, as is shown in section 5 below. A second and by no means minor problem has to do with their chronology of the changes, 
which suggests that the Way construction emerged as a distinct construction later than I believe was actually the case.

\subsection{Perek (2016)}

Unlike the studies summarised so far, the focus of Perek (2016) is essentially quantitative, his goal being to study changes in the productivity of the Way construction over the period 1830-2009. To this end, Perek draws on data from COHA and follows Israel (1996) in distinguishing between the three uses of the construction already mentioned. His comprehensive corpus-based analysis allows him to disclose an aspect of the Way construction that none of the previous studies had mentioned explicitly, namely that the path-creation sense (e.g. They bribed their way into city government) is by far the most common over the whole period investigated. For instance, in the first (1830-79) of the four subperiods into which Perek organises his data, the number of different verb types coding path-creation is 75 (2016: figure 2), as opposed to only 33 verb types in the case of the manner sense (2016: figure 3), and 11 in the case of the incidental-activity sense (2016: figure 4). This latter usage, as Perek observes, 'is clearly still a novelty in the first half of the 19th century, and remains marginal throughout the whole period of interest, despite a steady increase in frequency starting in the early 20th century' (2016: 6), a finding which confirms similar observations by Goldberg (1995: 203) and Israel (1996: 218, 224).

Perek's analysis has added much to our knowledge and understanding of the Way construction in modern times. However, since he only examines data from 1830 onwards, his findings can tell us little about the early history of the construction. A second, more serious shortcoming is that his uncritical reliance on Israel's tripartite semantic classification leads him to lump together usages of the Way construction that need to be kept apart, as will be discussed at greater length in section 6 below.

\section{Data sources}

Like my earlier research (Fanego 2012, 2017) on the development of various motion patterns in the history of English, the analysis of the Way construction and its precursors since OE times that is presented here draws on data gathered in various stages and from a variety of sources. The point of departure was the lists of verbs recorded in the Way construction in the literature on motion events. Specifically, the important monographs by Ogura (2002) and Huber (2017) have proved essential for Old and Middle English usage, as have my own lists of predicates occurring in the IMC and the Way construction since OE times; these were collected, as detailed in Fanego (2017: 40), from reference works such as An Anglo-Saxon Dictionary (B\&T; Bosworth, Toller \& Campbell 1898-1972), the Dictionary of Old English (DOE; Cameron et al. 2016), the MED (see above) and the Oxford English Dictionary (OED).

The qualitative data gathered from these various materials were supplemented with evidence retrieved from two large corpora of British and American English covering 
Table 1. Contents of CLMET3.0, per subperiod

\begin{tabular}{lrrrr}
\hline \hline & CLMET3.01 & CLMET3.02 & CLMET3.03 & \\
Genre & $1710-1780$ & $1780-1850$ & $1850-1920$ & TOTAL \\
\hline Narrative fiction & $4,642,670$ & $4,830,718$ & $6,311,301$ & $15,784,689$ \\
Narrative non-fiction & $1,863,855$ & $1,940,245$ & 958,410 & $4,762,510$ \\
Drama & 407,885 & 347,493 & 607,401 & $1,362,779$ \\
Letters & $1,016,745$ & 714,343 & 479,724 & $2,210,812$ \\
Treatise & $1,114,521$ & $1,692,992$ & $1,782,124$ & $4,589,637$ \\
Other & $1,434,755$ & $1,759,796$ & $2,481,247$ & $5,675,798$ \\
TOTAL & $10,480,431$ & $11,285,587$ & $12,620,207$ & $34,386,225$ \\
\hline \hline
\end{tabular}

Table 2. Contents of CEAL, per subperiod

\begin{tabular}{lccr}
\hline \hline Subcorpora & Number of texts (files) & Authors & \multicolumn{1}{c}{ Words } \\
\hline CEAL1 (1690-1780) & 42 & 40 & $1,484,463$ \\
CEAL2 (1781-1850) & 65 & 56 & $5,740,042$ \\
CEAL3 (1851-1920) & 87 & 45 & $6,319,792$ \\
TOTAL & 194 & 141 & $13,544,297$ \\
\hline \hline
\end{tabular}

the period 1700-1920, namely the Corpus of Late Modern English Texts, version 3.0 (CLMET3.0; De Smet et al. 2013), and the Corpus of Early American Literature (CEAL; Höglund \& Syrjänen 2016). CLMET3.0 is a collection of texts dating back to 1710-1920 and comprising five major genres, as indicated in table 1 . In total, the corpus contains 34 million words of running text, of which 20,547,199 correspond to narrative texts, fictional and non-fictional. Because of its size and composition, CLMET3.0 provides a solid basis for research on motion events, given the intimate connection between narration and frequency of motion descriptions (cf. Slobin 2004).

In turn, CEAL contains American English texts from 1690-1920. As shown in table 2, it is much smaller than CLMET3.0, and the genre distribution between the three subperiods it comprises is somewhat uneven. As its compilers point out, 'almost all of the texts included in CEAL1 are political writings, correspondence, journals, and religious texts' (Höglund \& Syrjänen 2016: 21). In CEAL2 the amount of fiction rises considerably to approximately 42 per cent of the texts. Lastly, CEAL3 consists almost solely of fictional texts; non-fiction covers only about 7 per cent of the subcorpus.

CLMET3.0 and CEAL will be employed in section 6 to offer a quantitative analysis of the Way construction in BrE and AmE over a period, 1700-1920, crucial in the formation of the construction and which to date has been covered only partly, in Perek's corpus-based study of AmE usage between 1830 and 2009. In addition to data from CLMET3.0 and CEAL, for some of the subschemas of the Way construction I will also adduce evidence from the decade 1980-1989, on the basis of the fiction component $(12,152,603$ words) in COHA. 
4 The Intransitive Motion construction: an overview

\subsection{Theoretical background: Goldberg's hierarchy of relationships between verbs and constructions}

This article, as will have been clear from the opening sections, adopts Goldberg's version of $\mathrm{CxG}$ (1995). In this model the clause structure is crucially seen as the result of an interaction between verbs and constructions, hence one of Goldberg's central concerns is to explore the range of possible semantic relationships that verbs can bear to constructions. One of her best-known proposals in this regard is Goldberg (1997), where she establishes the following hierarchy of possible relationships, arranged in order of decreasing prototypicality and frequency:

(7) Hierarchy of ways verbs can be related to constructions (based on Goldberg 1997: 396)

Elaboration $>$

Force-dynamic relation (manner, means, instrument, result, denial) $>$

Precondition, co-occurring activity

Elaboration is the most common type of relationship. In elaboration the verb simply designates an elaboration of the meaning of the construction, as is the case, for instance, with generic verbs like come, go and move in the IMC. There are cases, however, in which the verbs do not simply designate an elaboration of the constructional meaning, but add a further layer to it. Two examples of this adduced by Goldberg (1997: 387-8), each involving different subtypes of the Intransitive Motion construction, are the following:

(8) The bottle floated into the cave.

(9) The car screeched out of the driveway.

In (8) the floating is the manner in which the bottle moved into the cave, and in (9) the screeching is caused by, or is the result of, the motion. To account for the semantic relationships that the verbs bear to the constructions in such cases, Goldberg proposes to rely on FORCE DYNAMICS (Talmy 1985). Force dynamic relations are those relations that 'involve causes, forces, counterforces and tendencies' (Goldberg 1997: 393); invoking them enables Goldberg to accommodate the above relationships and various others also involving causation, such as means, instrument (Arthur wristed the ball over the net) and denial (Pat refused Chris a kiss); the latter two will not be discussed further here, since they are not directly relevant to the present research. Verbs, however, can be related to constructions in two further ways: precondition (Dave baked Elena a cake), which applies to certain ditransitive constructions, and co-occurrence, which can be seen at work in the two sentences in (10) (= examples (30) and (31) in Goldberg 1997: 395). These are to be interpreted, respectively, as He went along while whistling and He went out of the room while whistling; in these paraphrases two separate clauses (a main clause and a participial clause) are used instead of the more compact, simpler pattern in (10): 


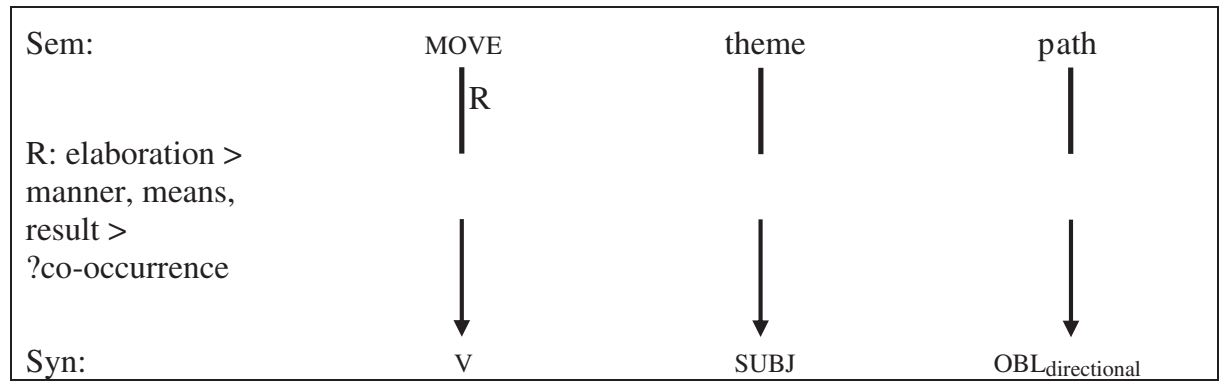

Figure 1. The Intransitive Motion construction in earlier English

(10) (a) He was whistling his way along.

(b) ?He whistled out of the room.

Example (10a) illustrates the incidental-activity thread of the Way construction, as discussed in section 2 above; (10b) is an example of the IMC which can be heard in some dialects but is judged unacceptable by most speakers of Standard English, as variously noted by Goldberg (1997: 395) and Rohde (2001: 245). Unlike examples (8)-(9) above, in the relationship of co-occurrence the verb designates a co-occurring activity that is not causally related to the action designated by the construction; it is correspondingly less common across languages (Goldberg 1997: 394-6) and 'not robustly represented in English' (Talmy 2000: II, 46).

\subsection{The Intransitive Motion construction in earlier English}

The connection between the Way construction and the IMC was hinted at by Goldberg when discussing examples such as Frank dug his way out of the prison (see (1b) above). She hypothesises that this usage could be viewed 'as a kind of conventionalized amalgam' that combines the syntax and semantics of creation expressions such as $\mathrm{He}$ made a path, which have two arguments, with the Intransitive Motion construction (He moved into the room), which also 'has two arguments - a mover (theme) and a path' (Goldberg 1995: 207).

To explore the nature of the interrelation between the Way construction and the IMC is one of the goals of this article, as noted at the beginning. To this end, the earlier history and characteristics of the IMC are summarised in the present section, based on the account in Fanego (2017). Here I proposed the representation of the IMC shown in figure 1. The notation is taken from Goldberg (1995: 61-5, 78), though with some adaptation; the formal side of the construction $(S y n)$ specifies a particular configuration of constituents; the semantic side (Sem) specifies an overall event meaning as well as a number of semantic roles corresponding to the constituents. In addition, the representation indicates the set of semantic relations $(R)$ that may hold between the event meaning provided by the construction and that provided by the verb. 
As can be seen in figure 1, the R-relations needed to account for the properties of the IMC over the course of history include five $\mathrm{e}^{3}$ out of the eight mentioned in section 4.1 above (see (7)). Four out of those five relations are briefly illustrated in what follows, namely elaboration, manner, means and result. A fifth relation, co-occurrence, is only attested twice in my comprehensive data from Old English to Present-day English (for details see Fanego 2017: 46-7), which confirms that this relationship is basically incompatible with the IMC in Standard English, as noted earlier.

\subsubsection{Elaboration and manner}

As pointed out above, verbs coding elaboration are neutral, basic items such as $\mathrm{OE}$ cuman 'to come', faran 'to go, travel', gan (gan) 'to go' or wendan 'to go, proceed'. In turn, verbs of manner of motion designate the manner in which the entity moves, that is, 'an ill-defined set of dimensions that modulate motion, including motor pattern, rate, rhythm, posture, affect, and evaluative factors' (Slobin 2004: 255). Predicates coding this relation in OE include ahealtian 'to limp, crawl', cleacian 'to go nimbly, hurry', creopan 'to crawl' and ef(e)stan 'to hurry', among many others (see (2) above for an example).

Together with elaboration, manner of motion constitutes the relation most frequently coded by the IMC today, as shown by Rohde (2001: 258-9). The same applies to earlier English: Huber's study of motion verb usage in Old and Middle English (2017: $118-19,187)$ concludes that the most frequently used verbs are verbs of elaboration, which overall account for 62 per cent of the verbs in the motion descriptions in ME, followed by manner verbs, with 31 per cent. The remaining 7 per cent in Huber's study is represented by path verbs (about 5 per cent), that is, verbs which include a specification of the direction of motion but not manner (e.g. ME departen 'to depart', entren 'to enter', etc.), and by non-motion verbs ( 2 per cent) such as those discussed in the next section.

\subsubsection{Means}

The relation of means pertains to the means by which the motion is achieved, either an action or a system of entities standing in for the action (Olofsson 2014: 4). Unlike the verbs of elaboration and manner of motion, means verbs do not inherently lexicalise motion, but can nevertheless receive a motion reading in context, when combined with a path satellite, through a process of COERCION (Michaelis 2003: 268).

Verbs lexicalising means are rarely used in the IMC in PDE, as shown by Rohde. Her study, which is based on '1358 instantiations of the IMC' (2001: 52) randomly selected from the 350 million-word North American News Text Corpus, found that the overwhelming majority of the verbs, namely 93.2 per cent, were verbs of motion (Rohde 2001: 244). The remaining 6.8 per cent consisted of a few much smaller non-

\footnotetext{
3 Fanego (2017: 42-3, 45-6) in fact distinguishes a sixth relation, namely SUBSEQUENCE, which can be seen at work in occurrences of the IMC with the English pre-modals (e.g. OE Ic to sae wille 'I wish [to go] to the sea'). The subsequence relationship has never been available with the Way construction (and hence it is not relevant for the present discussion).
} 
motion verb classes, such as verbs of sound emission (buzz, clatter, roar, rumble) and verbs of exerting force in a specified manner (blow, break, burst, cut, dig, erupt, plow, press, rip, squeeze). These latter correspond to what I am here calling verbs of means.

For the inventory of means verbs occurring in the IMC in earlier periods of English, I have relied on Huber's list (2017: appendixes A \& B) of non-motion verbs attested in motion constructions in Old and Middle English, which I supplemented with my own research and judgments on the semantics of individual verbs. On this basis, the group of $\mathrm{OE}$ verbs that can be safely characterised as related to motion by a relation of means comprises items such as (a)feohtan 'to fight (one's way)' (DOE 2); aredian 'to find, reach; to make one's way' (DOE C.2); berstan 'to burst or break into, to burst out' (DOE 3.a,b,c); brecan 'to break into, to break or burst through' (DOE 3.a,b, 4.a,c); secan 'to seek; to go or come to' (B\&T II.1.3); swincan 'to labour at, after, etc. anything' (B\&T I.a; not listed in Huber 2017); and winnan 'to strive, contend, fight; to win, make one's way' (B\&T A.III).

In ME the verbs in Huber's list which can be interpreted as means verbs include the reflexes of some of the means verbs already attested in the IMC in OE, that is, breken, bresten, sechen, swinken (in ME as 'to travel with effort', MED 2.c) and winnen, plus a few other items such as chesen 'to choose or take one's way' (MED 8) and ridden 'to clear (an area, a way) of opposing warriors' (not listed in Huber 2017, but cf. MED 1.b, c. 1400 KAlex 2234: He ... wizth gan aboute rede 'He ... at once began to clear [a way] towards every side'). Most of these verbs involve some kind of forceful, energetic action by which the motion is achieved, though this is not the case with OE aredian, ME chesen and OE secan/ME sechen. These seem to evoke the difficulty inherent in surveying and finding a path, rather than its actual creation by force (see in this regard, for instance, (11) below).

Two examples of means verbs used in the IMC in Old English are offered here; note that, in order to render the following quotations acceptable today, a way object would have to be supplied:

(11) lædst me hidres \& ðidres on swa picne wudu ðæt ic ne mæg ut aredian 'you lead me hither and thither into a wood so thick that I cannot find [my way] out' (Bo 35.100.4; DOE aredian C.2)

(12) pa gecwædon hie pæt ... sume purh ealle pa truman ut afuhten 'then they said that ... some would fight [their way] out through all the troops' (Or 5 7.121.27; DOE afeohtan v. 2)

\subsubsection{Result}

As pointed out in section 4.1 above, in the relation of result or, more fully, resultant sound (the car screeched out of the driveway), the co-event of sound - the screeching that is conflated with the main motion event results from this 'and would not otherwise occur' (Talmy 2000: II, 46). It follows from this, therefore, that this subschema of the IMC cannot accommodate verbs denoting sounds emitted via the vocal tract by an animate entity, such as bark, sing or wail, since with these the sound emitted by the physical entity does not arise from the motion itself. In order to avoid terminological 
Table 3. Sound-emission verbs newly recorded in the IMC, per subperiod

\begin{tabular}{ll}
\hline \hline$<1100$ & Verb types: 2 \\
\hline $1100-1500$ & New verb types: 10 \\
$1500-1700$ & New verb types: 10 \\
$1700-1920$ & New verb types: 46 \\
\hline \hline
\end{tabular}

Table 4. The result relation in CLMET3.0: number of occurrences of all sound-emission verbs recorded $(n=34)$

\begin{tabular}{lcc}
\hline \hline $1710-80$ & $1780-1850$ & $1850-1920$ \\
$(10,480,431$ words) & $(11,285,587)$ & $(12,620,207$ words) \\
\hline 12 (normalised frequency & 87 (normalised frequency & 214 (normalised frequency \\
per 100,000 words: 0.11$)$ & per 100,000 words: 0.77) & per 100,000 words: 1.69$)$ \\
\hline \hline
\end{tabular}

confusion, in the remainder of this article the ad hoc label SOUND-EMISSION VERB will be applied solely to those verbs (or verb uses) capable of occurring in the resultant sound subschema; all other sound verb classes will be referred to simply as SoUND VERBS.

Sound-emission verbs frequently attested in the result subschema of the IMC in modern times include, among others, boom, clatter, crash, patter, rattle, roar, rumble, rustle, splash, thunder, whistle and whizz (see Rohde 2001: 355; Fanego 2017: 56-65).

In the analysis of the result relation that I provided in earlier research, I showed that the occurrence of sound-emission verbs in the IMC can be traced back to OE, but remains uncommon until about the end of the eighteenth century, when a marked increase in both type and token frequency can be observed. Table 3, based on the findings in Fanego (2017), gives an overview of the new verb types entering the construction in each of the historical periods from OE onwards. Table 4 presents quantitative data on the occurrence of the result subschema in CLMET3.0.

In principle, it would be tempting to interpret the more frequent use of soundemission verbs just described simply as a manifestation of the overall tendency towards greater semantic specificity which has characterised the expression of motion events throughout the history of English (for details, see Fanego 2012). But this is not the only explanation, since the increase in frequency of the result subschema of the IMC is also a reflection of an important change in usage that has taken place in recent times, whereby from Late Modern English onwards sound-emission verbs have become vastly more common in all their uses, as I have discussed at length elsewhere (Fanego 2017: 62-7). The question of whether this change has also had consequences for the properties of the Way construction itself is considered in section 6 below. 


\subsubsection{Interim summary}

As is evident from the account in Fanego (2017) and the previous sections, throughout its recorded history the IMC has been specialised in the expression of relations of elaboration (He went into the house) and manner of motion (He walked out of the room). To these can be added, mostly from the LModE period, the relation of resultant sound (She rustled into the shop), which enabled speakers of English to further increase the expressivity of motion constructions by encoding information not just on the manner of the motion, but also on the kinds of sounds resulting from it. As regards the means subschema of the IMC (An enemy torpedo ripped through the hull of the ship), this has been attested from OE to the present day, but has always been restricted to just a small number of verbs, as discussed in section 4.2.2. Finally, unlike in other Germanic languages (for details, see Olofsson 2014: 4), the relation of co-occurrence is incompatible with the IMC in Standard English.

\section{The Way construction and its precursors}

The connection between the modern Way construction and a more general ME construction in which a verb of motion takes a path noun as optional argument, e.g. wente he his ride (c.1250), wente his wei (1390), etc., was clearly established by Israel (1996: 220-1) more than two decades ago, as summarised in section 2.1 above. The features of this general construction have also been addressed in some detail by Traugott \& Trousdale (2013: 80-1), who, like Israel, look exclusively at ME data; Israel's study, in fact, as becomes clear from his table 1 (1996: 226), only covers from 1374 onwards. However, since the motion pattern in question is attested already in $\mathrm{OE}$ times, it seems reasonable to start the analysis of the precursors of the Way construction from that period, rather than several centuries later.

The noun weg and its less frequent synonym stig 'path, (narrow) way' (B\&T s.vv. weg n., stīg n.; cf. also MED stie n. ${ }^{1}$ ) were employed in OE as apparent objects, in collocation with transitive verbs; they are attested also with intransitives, as adverbial accusatives or genitives indicating extent in space or the direction and path of movement (Mitchell 1985: I, §1382, §§1395-9; Ogura 2002: 61-5). In some of these uses weg, or on weg, served to translate Latin via, which had a similar semantic range (OED way n.; Ogura 2002: 63-4) and could be employed in motion patterns involving non-motion verbs such as committo 'to commit (to a place); (refl.) to venture' (Clare 2004 [1982] s.v. committo v. 10.b), or patefacio 'to open', e.g. vice se committere (Cic.) 'to take one's way' (Bravo et al. 1795 [1590]: 72); viam ferro patefacere (Tac.), ferro patefacere viam (Ter.) 'to open, make one's way with the sword' (van Peene 1818, s.v. patefacio). It is important to note that these collocations with via had acquired idiomatic status already in Latin, as is clear from the information provided by the phraseological dictionaries I have just quoted.

Turning now to OE, the intransitive verbs taking a weg argument include verbs of general meaning coding a relation of elaboration, as defined earlier, such as faran 'to go' (DOE I.A.4.b.i; I.C.1), gan 'to go, walk' (DOE I.3.b.ii: 'in glosses of Latin 
constructions with an accusative object') and gangan 'to go, walk' (DOE I.3.c.i); also occasionally manner of motion verbs such as ridan 'to ride on horseback' (B\&T I, Ors. 1.1: rídep célc hys weges 'each rides his way'). The transitives include a handful of verbs such as aredian 'to find, reach; to make one's way' (DOE C.1), geceosan 'to choose, seek out' (DOE 1.1.a; see Ogura 2002: 63), don 'to do, perform, make' (in glosses, for Lat. facere; Ogura 2002: 63), niman 'to take (one's way)' (B\&T VIII), ryman 'to clear a way' (B\&T II), (ge)wyrcan 'to make, do, perform' (B\&T, supplement s.v. wyrcan II.i.a; Ogura 2002: 63), and perhaps one or two others (see Ogura 2002: 63-4). Of these, aredian is also attested in the IMC (see (11) above), as is niman, which occurs with a weg object (e.g. B\&T VIII, GenA 1329b), but also intransitively (e.g. B\&T VIII.6). It is difficult to determine the exact semantic import of niman, but being a verb of very general meaning it probably contributed little to its clause beyond the meaning of the construction itself, so it will be classed here as a verb of elaboration. As regards aredian, geceosan, don, ryman and (ge)wyrcan, they code a relation of means of motion; the first two (aredian and geceosan), as already noted in section 4.2.2 above, evoke the difficulty inherent in surveying and finding a path, rather than a more energetic and forceful action.

Of the various verbs just mentioned, aredian 'to find, reach' collocated with weg quite frequently: according to the $D O E$, there are 40 occurrences of this verb in the extant OE records, seven with weg and one with its synonym stig. Ryman 'to clear a way' is also attested several times with weg (five instances in Ogura 2002: 62), as in (14) below.

(13) ðæt ðu grapie on midne dæg ... \& ðæt ðu ne mæge ðine wegas aredian 'so that you grope at midday ... \& be unable to find your way' (Deut 28.28; cf. Dt 28:29 non dirigas vias tuas; DOE aredian C.1)

(14) Hi becomon ða eft to ðam witniedlicum fyre, and se gewæpnoda engel rymde him weg purh pæt fyr. todælende ðone lig on emtwa 'They then came again to the penal fire, and the armed angel cleared a way for them through the fire, dividing the flame in two' (ÆCHom II.344, 13; B\&T ryman v. II.)

(15) Weg pu weortest on sæ

'You made [your] way on the sea' (Lat. uiam fecisti in mari, Ps. L. Lind. 242, 20;

B\&T, supplement s.v. wyrcan II.i.a)

Summing up, the OE data are consistent with ME usage, as described by Israel (1996) and Traugott \& Trousdale (2013), whose earliest examples refer to some of the verbs mentioned above, such as go, nim (OE niman/ME nimen 'to take') and ride. Israel (1996: 221, 223) and Traugott \& Trousdale (2013: 78, 80, 84-5) also mention three other predicates not attested with weg in OE, namely find, make and take. But these are synonymous with several of the OE verbs listed earlier: find replaced $\mathrm{OE}$ aredian/ME areden 'to find' when this latter verb went out of use in the early fourteenth century (MED areden $\mathrm{v}^{2}$ ). Make represents OE macian, whose 
Table 5. 1100-1587: verb types occurring in the patterns [SUBJ $V_{i} \mathrm{POSS}_{i}$ way] and $\left[S U B J_{i} V P O S S_{i}\right.$ way $\left.O B L_{\text {directional }}\right]$

\begin{tabular}{|c|c|c|}
\hline Verb type & Meaning & R-relation \\
\hline faren & 'to go' & Elaboration \\
\hline fongen & 'to take' (MED fongen 1(c); Huber 2017: 228) & Elaboration \\
\hline gon & 'to go' & Elaboration \\
\hline holden (forth) & 'to proceed on one's way, go' (MED holden $\left.{ }^{1} 21(\mathrm{~b})\right)$ & Elaboration \\
\hline marken & 'to take (a road), follow a route' $\left(M E D\right.$ marken $\left.^{2}(\mathrm{~b})\right)$ & Elaboration \\
\hline nimen & 'to take' & Elaboration \\
\hline passen forth & 'to go forth, go on, proceed' (MED passen 1.c(d)) & Elaboration \\
\hline taken & 'to take' & Elaboration \\
\hline walken forth & 'to set out, go forth; go away' (MED walken $2 \mathrm{~b}$ ) & Elaboration (?) \\
\hline wenden & 'to follow a course, take one's way' (MED wenden 3(a)) & Elaboration \\
\hline driven forth & 'to sail, travel by sea' (MED driven 7.a(c); wei $2 . \mathrm{b}(\mathrm{b}))$ & Manner \\
\hline flen / flien & $\begin{array}{l}\text { 'to run away, flee' (MED flen 1(a)); 'to fly with wings' } \\
\text { (MED flien 1.a(a)); 'to hasten, hurry' (MED 3.a(a)) }\end{array}$ & Manner \\
\hline hasten & 'to make haste, to hurry' (MED hasten 2(c)) & Manner \\
\hline rennen & 'to run' & Manner \\
\hline riden & 'to ride' & Manner \\
\hline shapen & 'to direct (one's way)' (MED shapen 7(a); wei $2 . \mathrm{b}(\mathrm{e})$ ) & Manner (?) \\
\hline turnen & $\begin{array}{l}\text { 'to change course so as to go in a different direction' } \\
\text { (MED turnen } 16(\mathrm{a})) \text {; 'to make one's way back to a } \\
\text { place' (MED turnen 19a(a)) }\end{array}$ & Manner \\
\hline chesen & 'to choose' & Means \\
\hline finden & 'to find' & Means \\
\hline maken & 'to make' & Means \\
\hline ridden & 'to clear a way' (MED ridden $1(\mathrm{~b}) ;$ OED redd $1 . \mathrm{c})$ & Means \\
\hline rimen & 'to clear a way' (MED rimen $\mathrm{v}^{3}$ (a)) & Means \\
\hline sechen & 'to seek' & Means \\
\hline
\end{tabular}

usual sense in OE was 'to bring into existence; to construct'; in its current modern sense it was much less common than OE don 'to do, make' (the word most commonly used to translate Lat. facere) and (ge)wyrcan 'to make' (B\&T and supplement; OED s.v. make). Finally, take (OE tacan) is a borrowing from early Scandinavian with very few attestations in OE; during the course of ME it gradually superseded the native verb nim (B\&T s.v. tacan, OED s.v. take).

The above information on OE and ME usage can be usefully supplemented with the list of verbs which occurred, between 1100 and $1587,{ }^{4}$ in the way patterns of greater interest for our purposes here, that is, those containing a possessed argument coindexed with the higher subject. This list, presented as table 5, is based on the comprehensive $M E D$ entry for the noun wei and the $O E D$ quotation database (which Israel also used for his own analysis). As can be seen, elaboration verbs (10) predominate, followed by

4 The time span 1100-1587 was chosen so that it coincided, at least partly, with the dates of the earliest period (1374-1587) examined by Israel. 
manner verbs (7) and means verbs (6); most verb types attested are quite general in meaning.

In addition to the increase in productivity of the way patterns which seems to be apparent when we compare the information in table 5 with the smaller number (10) of verb types that collocated with weg in $\mathrm{OE}$, the other major development taking place from ME onwards relates to the growing obligatorification of the directional argument. In late ME this was most often absent, as has been shown by Israel (1996: 226) on the basis of the $O E D$ quotation database: out of Israel's 40 tokens attested with way in the period 1374-1587, some 24 (=60\%) lack a directional phrase; by 1946-60, the figure has fallen to just $4(=5 \%)$ out of 74 tokens, so that the construction has settled into the rigid syntax that characterises it today. The presence of the directional argument is of course essential to argue that the Way construction, as we understand it now, has effectively entered the grammar, and most particularly, it is the prerequisite for it to constitute an alternative to the IMC. In my view, this already happens in ME times, as is suggested by the examples below, among many others which could be adduced from my sources. Traugott \& Trousdale's (2013: 84-5) dating of the Way construction to the end of the seventeenth century, to which I referred in section 2.2 above, therefore seems far too late.

(16) Corineus ... harde smot ... \& made is wey bi eiper side, \& percede pe route.

'Corineus ... struck hard ... \& made his way in every direction \& pressed into the enemy ranks.' (c.1325 (c.1300) Glo.Chron.A (Clg A.11) 391; MED percen 3.a)

(17) To me tended pei nouzt, but tok forp here wey wilfulli to sum wildernesse 'They did not pay attention to me, but took their way wilfully to a wilderness' (a.1375 William of Palerne (1867) 1. 1781; OED tend $\mathrm{v}^{2}$ 1.a)

(18) Me thoght I sih a barli cake, Which fro the Hull his weie hath take, And cam rollende doun at ones.

'I thought I saw a barley cake, which had taken its way from the hill, and came rolling down at once.' (a.1393 Gower Confessio Amantis (Fairf). vii. 3707; MED barli, n. 3(a))

(19) To London, vnto Eilred, hasted pei per weie.

(?a.1400(a.1338) Mannyng Chron.Pt.2 (Petyt 511 p. 47; MED hasten 2.b)

(20) With swerdis dynt behuffis ws, Throw amyddis our ennemys red our way.

'[It] behoves us by force of arms, [to] clear our way through among our enemies.' (1513 G. Douglas tr. Virgil AEneid x. vii. 30; OED redd v. ${ }^{2}$ 1.c.)

As can be observed, these early examples are all relatively compositional, with the noun way still encoding a fairly concrete notion of a path that is tangible; this was to be expected: the development of the Way construction, as we know from the literature, started with the expression of concrete motion, abstract types of motion, as Perek puts it, being 'plausibly derived as metaphorical extensions of attested concrete uses with specific verbs' (2016: 22). 
Also worthy of notice is the surface syntax of examples (17)-(20), where facts of preposing and discontinuity between the way phrase and the directional phrase, and possibility of adjunct insertion (wilfulli, in (17)) after the way phrase show that the directional phrase cannot be parsed as a postmodifier of way, but as a separate constituent under VP, that is, a separate argument. In other words, the construction appears to exhibit the constituency and surface syntax which it has in PDE (for discussion, see Jackendoff 1990: 211-12). Overall, therefore, the historical data point to the following development: a first stage in which a relatively small group of verbs and a way phrase would frequently occur together to designate motion along a path (go one's way, make one's way, take one's way, etc.), until they eventually cohered to form a more complex unit of memory organisation, i.e. a 'chunk' (cf. Bybee 2010: 347). This larger unit would subsequently have been combined with a directional phrase indicating the goal of the motion, an innovation which enabled the Way construction to compete with the IMC, the other major construction of intransitive directed motion existing in English.

After this overview of the precursors and early history of the Way construction, the next section turns to its development from 1700 onwards, on the basis of the corpora detailed in section 3 .

\section{The Way construction from 1700 onwards}

In her seminal analysis of the Way construction, Goldberg observed that so-called 'vanilla motion' verbs, that is, high-frequency, monomorphemic verbs such as go, walk, run, step and move, 'are typically unacceptable in [the] construction' (1995: 205):

(21) *She went/walked/ran/stepped/moved her way to New York.

This claim appears to be largely true for at least the verbs go and take. Based on two large fiction samples covering the periods 1460-1700 and 1960-93, Mondorf has shown (2011: 409) that the ratio of occurrence of go in Way constructions (e.g. He went his way to the alehouse) has decreased dramatically in the course of time. A similar comment applies to take: take one's way, like go one's way itself, survives in the grammar of PDE only as an archaism, as is evident from a quick search in COHA. These findings reflect the gradual development of the Way construction from its primary, original function of expressing motion on a stretch of gravel, grass, mud and the like, to its increasingly grammaticalised use today, where the motion meaning is expressed by the construction as a whole. This, as Mondorf notes, leaves the verb free to assume the important role of coding whatever additional information needs to be transmitted, for instance, the kind of incidental activity co-occurring with the motion (e.g. She giggled her way up the stairs). Vanilla motion verbs, being generic and semantically neutral, are unfit for that role and therefore are 'regarded as redundant' (Mondorf 2011: 409). 
In addition to this important development that has affected the Way construction in modern times, I would like to draw attention in this section to the fact that the entrenchment of the Way construction from ME onwards seems to have resulted in a division of labour between it and the IMC. By comparison to other English motion constructions, the syntactic frame of the IMC (SUBJ V OBL) is relatively inexplicit. For instance, the Caused-Motion construction (Goldberg 1995: 152-79) in (22) contains two participants, an agent (John, Frank) and a moving figure (the ball, the tissue); the agent is 'the source of the figure's motion in a physical as well as a spatial sense' (Rohde 2001: 286), which brings about quite naturally a notion of directionality as well as dynamicity. This explains why the Caused-Motion construction can readily accommodate in its syntactic frame non-motion verbs such as sneeze in (22b).

(22) (a) John threw the ball over the fence.

(b) Frank sneezed the tissue off the table.

The IMC, by contrast, lacks a second participant and is thus far less specified. As Rohde observes (2001: 287), 'the single participant is AGENT and FIGURE at the same time'. This reduces the power of the construction, which, as we saw in section 4 above, has been used since OE times chiefly with verbs predicating motion, to code relations of elaboration (go, move) and manner (ride, climb).

In turn, the Way construction expresses intransitive motion, as does the IMC, but contains both a lexically specified element referring to the path of motion (the way argument) and a goal argument. The constructional template is, therefore, far more explicit than that of the IMC and offers a lot of freedom for the choice of verb. One could thus predict that as the Way construction increased its productivity in the course of time, it would tend to be preferably used to code those R-relations that either cannot be expressed at all by the IMC (such as co-occurrence) or can be expressed less easily (such as means of motion).

Thanks to Perek's quantitative study (2016) of the Way construction, we know that the above prediction is indeed correct as regards the means relation; this shows a steep increase in frequency over the period investigated by Perek, namely 1830-2009 (Perek 2016: 7-8), and particularly from the 1890s onwards. For the co-occurrence relation, however, the information offered by Perek is not wholly accurate. Like Israel (1996: 222) and Traugott \& Trousdale (2013: 78, example (28d), 87) before him, Perek (2016: 18) lumps together under the heading of incidental action (his label for what I am calling the R-relation of co-occurrence) cases which clearly do not belong in that category. Witness in this respect the following examples adduced by Perek in his discussion of the 'incidental-action sense' in his section 4.4:

(23) Others died under his knife, or babbled their way to eternity in a fog of opium. (1995)

(24) The tractor began to thump its way into the wheat belt. (1935)

Whereas (23), containing the manner of speaking verb babble, indeed illustrates the co-occurrence subschema ('Others ... departed to eternity while babbling at the same time'), (24) does not. This latter involves the sound-emission verb thump and is a classic example of the resultant sound subschema (the thumping results from the tractor's 
Table 6. The Way construction: overview of verb types and R-relations in CLMET3.0 and CEAL

\begin{tabular}{ll}
\hline \hline Corpus and subperiod & \multicolumn{1}{c}{ Verb types and R-relations } \\
\hline CLMET3.01 (1710-1780), 10,480,431 words & $\begin{array}{l}\text { Elaboration: } 3(12 \text { tokens }=6.98 \%) \\
\text { Manner of motion: } 3(9 \text { tokens }=5.2 \%)\end{array}$ \\
& Means: $17(151$ tokens $=87.8 \%)$ \\
CEAL1 (1690-1780), 1,484,463 words & Elaboration: $1(1$ token $=5 \%)$ \\
& Manner of motion: $1(1$ token $=5.0 \%)$ \\
& Means: $4(18$ tokens $=90.0 \%)$ \\
CLMET3.03 (1850-1920), 12,620,207 words & Elaboration: $2(8$ tokens $=1.5 \%)$ \\
& Manner of motion: $20(60$ tokens $=11.54 \%)$ \\
& Means: $46(448$ tokens $=86.15 \%)$ \\
& Resultant sound: $1(1$ token $=0.19 \%)$ \\
CEAL3 (1851-1920), 6,319,792 words & Co-occurrence: $3(3$ tokens $=0.58 \%)$ \\
& Elaboration: $4(10$ tokens $=2.25 \%)$ \\
& Manner of motion: $16(38$ tokens $=8.56 \%)$ \\
& Means: $40(394$ tokens $=88.74 \%)$ \\
& Resultant sound: $2(2$ tokens $=0.45 \%)$ \\
\hline
\end{tabular}

motion); it is therefore not comparable to the other example, neither semantically nor in terms of its historical development, as will be shown later in this section.

In order to examine in detail this and other aspects of usage, I carried out a study based on the two large corpora of British and American English described in section 3 above, namely CLMET3.0 (1710-1920) and CEAL (1690-1920). For both corpora I considered only subperiods 1 (covering until 1780) and 3 (1850-1920). In the case of subperiod 1 the data in tables 6-7 refer to all tokens of the Way construction retrieved after a search for the noun way. In subperiod 3, however, the analysis was restricted to the first 6,351 hits recorded in CLMET3.03 (out of a total of 12,702) and the first 4,050 hits recorded in CEAL3 (out of a total of 8,099). ${ }^{5}$

A number of aspects deserve mention in relation with the information in tables 68. Firstly, the absence of major differences in usage between the two supranational varieties of English - British and American. In subperiod 1 (1690-1780) the normalised frequencies of the Way construction per 100,000 words in both varieties are roughly comparable at 1.64 and 1.34 respectively, and the slight difference here might have to do with the different genre balance of CLMET3.01 and CEAL1 mentioned in section 3 above. Likewise, both varieties show steep increases in frequency, in terms of both types and tokens, from subperiod 1 to subperiod 3 (1850-1920), as was to be expected in view of the overall development of the construction outlined in Israel (1996). And lastly, the predicates entering the Way construction in both varieties largely coincide, with two generic predicates familiar from earlier periods, find and make, being by far the most common. All this suggests that, as already argued in section 5

5 In CLMET3.01 and CEAL1, the hits for the search word way were 6,004 and 1,047 respectively. 
Table 7. The Way construction in CLMET3.01 (1710-1780; 10,480,431 words) and CEAL1 (1690-1780; 1,484,463 words)

\begin{tabular}{|c|c|c|c|}
\hline \multicolumn{2}{|c|}{ CLMET3.01 } & \multicolumn{2}{|c|}{ CEAL1 } \\
\hline $\begin{array}{l}\text { Verb types and } \\
\text { R-relations }\end{array}$ & $\begin{array}{l}\text { No. of } \\
\text { tokens }\end{array}$ & $\begin{array}{l}\text { Verb types and } \\
\text { R-relations }\end{array}$ & $\begin{array}{l}\text { No. of } \\
\text { tokens }\end{array}$ \\
\hline bend (manner) & 3 & - & - \\
\hline break (means) & 1 & - & - \\
\hline burst (means) & 1 & - & - \\
\hline cut (means) & 14 & - & - \\
\hline direct (manner) & 1 & - & - \\
\hline eat (means) & 3 & - & - \\
\hline explore (means) & 4 & - & - \\
\hline feel (means) & 1 & - & - \\
\hline fight (means) & 3 & - & - \\
\hline find (means) & 36 & find (means) & 4 \\
\hline force (means) & 30 & force (means) & 2 \\
\hline- & - & gnaw (means) & 1 \\
\hline go (elaboration) & 1 & - & - \\
\hline grope (means) & 2 & - & - \\
\hline hold (elaboration) & 1 & - & - \\
\hline make (means) & 44 & make (means) & 11 \\
\hline push (means) & 2 & - & - \\
\hline rend (means) & 1 & - & - \\
\hline seek (means) & 1 & - & - \\
\hline take (elaboration) & 10 & take (elaboration) & 1 \\
\hline- & - & urge (manner) & 1 \\
\hline weather (means) & 1 & - & - \\
\hline win (means) & 2 & - & - \\
\hline wing (manner) & 5 & - & - \\
\hline work (means) & 5 & - & - \\
\hline Total types: 23 & $\begin{array}{l}\text { Total tokens: } 172 \\
\text { (frequency normalised } \\
\text { per } 100,000 \text { words: } \\
1.64 \text { ) }\end{array}$ & Total types: 6 & $\begin{array}{l}\text { Total tokens: } 20 \\
\text { (frequency normalised } \\
\text { per } 100,000 \text { words: } \\
1.34 \text { ) }\end{array}$ \\
\hline
\end{tabular}

above, the basic features of the Way construction must have been in place well before the start of the Colonial period in 1607.

As regards R-relations, the data show (see especially table 6) that throughout the period examined the role of elaboration verbs is marginal, with just a few occurrences of hold (2), keep (1), go (5) and take (23). The frequencies of the last two predicates, as pointed out at the beginning of this section, have continued to decline, until they have become restricted to a few specialised, idiomatic usages. The means relation is by far the most common, with percentages of 87.8 in CLMET3.01, 90.0 in CEAL1, 86.15 in CLMET3.03 and 88.74 in CEAL3. By contrast, the manner relation is infrequent in terms of both types (40) and tokens (108), with token percentages ranging from 
Table 8. The Way construction in CLMET3.03 (1850-1920; 12,620,207 words) and CEAL3 (1851-1920; 6,319,792 words)

\begin{tabular}{|c|c|c|c|}
\hline \multicolumn{2}{|l|}{ CLMET3.03 } & \multicolumn{2}{|l|}{ CEAL3 } \\
\hline $\begin{array}{l}\text { Verb types and } \\
\text { R-relations }\end{array}$ & $\begin{array}{l}\text { No. of } \\
\text { tokens }\end{array}$ & $\begin{array}{l}\text { Verb types and } \\
\text { R-relations }\end{array}$ & $\begin{array}{l}\text { No. of } \\
\text { tokens }\end{array}$ \\
\hline beat (means) & 1 & beat (means) & 3 \\
\hline beg (means) & 2 & beg (means) & 1 \\
\hline bend (manner) & 3 & - & - \\
\hline blast (means) & 1 & - & - \\
\hline- & - & blaze (means) & 1 \\
\hline bob (manner) & 1 & - & - \\
\hline bore (means) & 1 & - & - \\
\hline bounce (manner) & 1 & - & - \\
\hline break (means) & 3 & break (means) & 1 \\
\hline bump (manner) & 1 & - & - \\
\hline burn (means) & 1 & burn (means) & 1 \\
\hline burst (means) & 2 & - & - \\
\hline carve (means) & 1 & - & - \\
\hline- & - & churn (manner) & 1 \\
\hline- & - & chop (means) & 1 \\
\hline claw (means) & 1 & claw (means) & 1 \\
\hline clear (means) & 1 & - & - \\
\hline cleave (means) & 3 & - & - \\
\hline crush (means) & 2 & crush (means) & 1 \\
\hline cut (means) & 6 & cut (means) & 13 \\
\hline delve (means) & 1 & - & - \\
\hline- & - & $\operatorname{dig}$ (means) & 2 \\
\hline- & - & drag (manner) & 2 \\
\hline eat (means) & 8 & eat (means) & 4 \\
\hline edge (manner) & 1 & edge (manner) & 4 \\
\hline elbow (means) & 6 & elbow (means) & 4 \\
\hline explore (means) & 1 & - & - \\
\hline feel (means) & 25 & feel (means) & 28 \\
\hline fight (means) & 7 & fight (means) & 26 \\
\hline find (means) & 106 & find (means) & 47 \\
\hline flap (manner) & 2 & - & - \\
\hline- & - & fling (manner) & 1 \\
\hline force (means) & 23 & force (means) & 11 \\
\hline forge (means) & 2 & - & - \\
\hline fumble (means) & 1 & fumble (means) & 1 \\
\hline gasp (co-occurrence) & 1 & - & - \\
\hline go (elaboration) & 2 & go (elaboration) & 2 \\
\hline grope (means) & 20 & grope (means) & 17 \\
\hline- & - & hew (means) & 1 \\
\hline- & - & hitch (manner) & 1 \\
\hline- & - & hold (elaboration) & 1 \\
\hline- & - & keep (elaboration) & 1 \\
\hline
\end{tabular}


Table 8. Continued

\begin{tabular}{|c|c|c|c|}
\hline \multicolumn{2}{|l|}{ CLMET3.03 } & \multicolumn{2}{|l|}{ CEAL3 } \\
\hline $\begin{array}{l}\text { Verb types and } \\
\text { R-relations }\end{array}$ & $\begin{array}{l}\text { No. of } \\
\text { tokens }\end{array}$ & $\begin{array}{l}\text { Verb types and } \\
\text { R-relations }\end{array}$ & $\begin{array}{l}\text { No. of } \\
\text { tokens }\end{array}$ \\
\hline make (means) & 116 & make (means) & 133 \\
\hline mine (means) & 1 & - & - \\
\hline- & - & mow (means) & 1 \\
\hline- & - & nudge (means) & 1 \\
\hline- & - & pave (means) & 1 \\
\hline- & - & pay (means) & 2 \\
\hline peck (means) & 1 & - & - \\
\hline pick (means) & 17 & pick (means) & 14 \\
\hline- & - & play (means) & 1 \\
\hline plod (manner) & 2 & - & - \\
\hline plough (means) & 5 & plough (means) & 2 \\
\hline poke (means) & 2 & - & - \\
\hline- & - & press (means) & 1 \\
\hline pull (means) & 1 & - & - \\
\hline purr (co-occurrence) & 1 & - & - \\
\hline push (means) & 21 & push (means) & 22 \\
\hline rake (manner) & 1 & - & - \\
\hline reason (means) & 2 & - & - \\
\hline- & - & rend (means) & 1 \\
\hline$r u b$ (co-occurrence) & 1 & - & - \\
\hline- & - & scent (means) & 1 \\
\hline- & - & scramble (manner) & 1 \\
\hline scrape (means) & 2 & - & - \\
\hline scratch (means) & 1 & - & - \\
\hline screw (manner) & 1 & - & - \\
\hline- & - & seek (means) & 1 \\
\hline shape (means) & 1 & - & - \\
\hline shoulder (means) & 1 & shoulder (means) & 3 \\
\hline- & - & shriek (resultant sound) & 1 \\
\hline- & - & slam (means) & 1 \\
\hline slash (means) & 1 & - & - \\
\hline splash (resultant sound) & 1 & splash (resultant sound) & 1 \\
\hline squeeze (means) & 1 & - & - \\
\hline steal (manner) & 1 & - & - \\
\hline storm (manner) & 2 & - & - \\
\hline take (elaboration) & 6 & take (elaboration) & 6 \\
\hline- & - & tap (manner) & 1 \\
\hline tear (means) & 1 & tear (means) & 1 \\
\hline think (means) & 1 & - & - \\
\hline thread (manner) & 14 & thread (manner) & 10 \\
\hline- & - & thrust (manner) & 2 \\
\hline- & - & tiptoe (manner) & 2 \\
\hline
\end{tabular}


Table 8. Continued

\begin{tabular}{|c|c|c|c|}
\hline \multicolumn{2}{|c|}{ CLMET3.03 } & \multicolumn{2}{|c|}{ CEAL3 } \\
\hline $\begin{array}{l}\text { Verb types and } \\
\text { R-relations }\end{array}$ & $\begin{array}{l}\text { No. of } \\
\text { tokens }\end{array}$ & $\begin{array}{l}\text { Verb types and } \\
\text { R-relations }\end{array}$ & $\begin{array}{l}\text { No. of } \\
\text { tokens }\end{array}$ \\
\hline toddle (manner) & 1 & - & - \\
\hline track (manner) & 1 & - & - \\
\hline twine (manner) & 1 & - & - \\
\hline twist (manner) & 1 & twist (manner) & 1 \\
\hline wear (means) & 1 & wear (means) & 1 \\
\hline- & - & wedge (means) & 1 \\
\hline wend (manner) & 10 & wend (manner) & 5 \\
\hline win (means) & 7 & win (means) & 5 \\
\hline wind (manner) & 7 & wind (manner) & 3 \\
\hline wing (manner) & 5 & wing (manner) & 1 \\
\hline work (means) & 31 & work (means) & 33 \\
\hline worm (manner) & 4 & worm (manner) & 5 \\
\hline worry (means) & 1 & - & - \\
\hline wrestle (means) & 1 & wrestle (means) & 1 \\
\hline- & - & zigzag (manner) & 1 \\
\hline Total types: 72 & Total tokens: 520 & Total types: 62 & Total tokens: 444 \\
\hline
\end{tabular}

5.23 in CLMET3.01 and 5 in CEAL1 to 11.54 in CLMET3.03 and 8.56 in CEAL3. In view of these relatively modest figures, Israel's assertion (1996: 224) that in the nineteenth century 'the manner thread experiences a rapid expansion' does not seem fully justified, especially if we recall that during the modern period the number of manner of motion verbs increased enormously, as I have shown elsewhere (Fanego 2012: 50-7). So the increase in the manner of motion types occurring in the Way construction in subperiod 3 is hardly proportionate to the changes undergone by the manner of motion lexicon over the same period.

In any case, it is true that the relation of manner constitutes the major area of constructional overlap between the Way construction and the IMC. Both are equally suited to express manner of motion, as can be seen in the following two examples:
(a) I have now been something like five hours on the tramp, plodding my way through a deep glen in a pine forest, (CLMET3.03 1890 Punch, 16 August)
(b) for an hour they had been plodding through grey solitudes, (CLMET3.03 1893 George Gissing, The Odd Women)

In addition to elaboration, manner and means, R-relations of resultant sound and cooccurrence are also represented in the two corpora examined here (see table 6 above). From a quantitative point of view these relations are marginal in my data, yet the fact that they have not always been properly understood in the earlier literature on the Way construction merits attention, and thus they will be addressed in a separate section. 


\subsection{Resultant sound and co-occurrence}

The frequent use in the Way construction, mostly from the twentieth century onwards, of different types of verbs describing sound emission has often been noted, initially by Israel (1996: 222-3, 225) and subsequently by Traugott \& Trousdale (2013) and Perek (2016: 18,23). Israel ascribes uses such as (26) below to the manner of motion thread, and those like (27) to the co-occurrence relation (which he calls incidental activity).

(26) The cars that ... clanged their way past Wayne were filled to the running-boards (1917 Mathewson; quoted from Israel 1996: 223)

(27) He ... whistled his way to the main front-door. (1866 Blackmore; quoted from Israel 1996: 225)

In turn, Traugott \& Trousdale (2013: 87-8) subsume both of the above uses under the relation of co-occurrence ('accompaniment', in their terminology), as does Perek. Perek (2016: 8, 17-18) notes, too, that especially from 1930 onwards there has been a steady increase in frequency of the co-occurrence relation, so that, comparatively, this has now become the most productive use of the Way construction. Based on extensive data from COHA for the period 1830-2009, he enumerates some of the semantic classes of verbs which, according to him, enter the co-occurrence relation (2016: 18); they include (using Perek's labels) ingestion verbs (drink, eat, smoke, etc.), performance verbs (chant, dance, play, sing, whistle), bodily functions verbs (cough, sweat, vomit, etc.), noise verbs (clatter, rattle, rumble, thump, etc.), speech verbs (apologize, babble, curse, swear, thank, etc.), cry verbs (roar, scream, shout, etc.), and verbs of 'other human sounds' (gasp, groan, weep, etc.).

As I pointed out in the previous section (see also section 2.3), the problem with Perek's classification (and equally with Traugott \& Trousdale's) is that it lumps together uses of verbs of sound emission which denote a force-dynamic (i.e. causal) relation between the activity expressed by the verb and the constructional semantics, as in (24) above with the verb thump and (28) from my own data, and genuine cases of cooccurrence such as (27) above and (29) below, in which the action described by the verb merely occurs concomitantly with the motion, but is in no way caused by it. This has the effect of obscuring any differences that might exist in the behaviour of these two uses of English sound verbs.

(28) The native ... waited until the saw had shrieked its way through the log of oak, (CEAL3 1907 Harold B. Wright, The Shepherd of the Hills)

(29) A favourite animal, white as snow, brought by one of the visitors, purred its way gracefully among the wine-cups, (CLMET3.03 1885 Walter Pater, Marius the Epicurean)

A question that emerges, therefore, is whether the marked increase in the cooccurrence relation which Perek reports during the twentieth century applies both to the co-occurrence relation properly speaking and to the relation of resultant sound, or only to the former. In order to check this, I made use of the set of 34 soundemission verbs attested in motion constructions in CLMET3.0 (see Fanego 2017: 634 and table 4 above). This set served as the basis for a comparative analysis of all 
Table 9. Sound-emission verbs recorded in the resultant-sound relation in three historical corpora ${ }^{6}$

\begin{tabular}{|c|c|c|c|}
\hline $\begin{array}{l}\text { Set of } 34 \text { verbs } \\
\text { examined }\end{array}$ & $\begin{array}{c}\text { CLMET3.03 } \\
(1850-1920 ; \\
12,620,207 \text { words })\end{array}$ & $\begin{array}{c}\text { CEAL3 } \\
(1851-1920 ; \\
6,319,792 \text { words })\end{array}$ & $\begin{array}{c}\text { COHA Fiction } \\
\text { (1980-9; } 12,152,603 \\
\text { words })\end{array}$ \\
\hline $\begin{array}{l}\text { boom, buzz, } \\
\text { clamp/clomp/clump, } \\
\text { clank, clatter, clink, } \\
\text { crash, creak, crunch, } \\
\text { fizz, hiss, hum, hurtle, } \\
\text { jingle, patter, pipe, } \\
\text { plash, rattle, roar, } \\
\text { rumble, rustle, } \\
\text { scream, sing, spatter, } \\
\text { splash, squeal, } \\
\text { squelch, swish, } \\
\text { thump, thunder, } \\
\text { tinkle, whirr, whistle, } \\
\text { whizz }\end{array}$ & $\begin{array}{l}\text { No. of occurrences } \\
\text { in the IMC: } 179 \\
\text { No. of occurrences } \\
\text { in the Way } \\
\text { construction: 1, } \\
\text { with the verb } \\
\text { splash. } \\
\text { E.g. } 1865 \text { Carroll, } \\
\text { Alice's Adventures } \\
\text { in Wonderland: } \\
\text { 'the frightened } \\
\text { Mouse splashed } \\
\text { his way through } \\
\text { the neighbouring } \\
\text { pool' }\end{array}$ & $\begin{array}{l}\text { No. of occurrences } \\
\text { in the IMC: } 180 \\
\text { No. of occurrences } \\
\text { in the Way } \\
\text { construction: } 2 \text {, } \\
\text { with the verbs sing } \\
\text { and splash. } \\
\text { E.g. } 1907 \text { van Dyke, } \\
\text { Days Off: 'He } \\
\text { knew all the cold, } \\
\text { foaming, musical } \\
\text { brooks that sang } \\
\text { their way down } \\
\text { from the hills.' }\end{array}$ & $\begin{array}{l}\text { No. of occurrences } \\
\text { in the IMC: } 474 \\
\text { No. of occurrences } \\
\text { in the Way } \\
\text { construction: } 3 \text {, } \\
\text { with the verbs } \\
\text { clatter, rustle and } \\
\text { thump. } \\
\text { E.g. } 1986 \text { Scott } \\
\text { Rohan, Anvil of } \\
\text { Ice: 'A little way } \\
\text { along the line of } \\
\text { bushes something } \\
\text { else was } \\
\text { rustling its way } \\
\text { forward,' }\end{array}$ \\
\hline
\end{tabular}

occurrences of the verbs in question, in both the IMC and the Way construction, in three different subcorpora, namely CLMET3.03, CEAL3 and the Fiction component in COHA, decade 1980-9. An overview of the results obtained is offered in table 9. It shows, first, that by the end of the twentieth century the IMC remains the default choice to code resultant sound; the Way construction, though possible, is very rarely used for such a purpose. From this we can conclude that the increase in productivity mentioned by Perek has to be interpreted as applying mostly to the co-occurrence subschema (He whistled his way to the main front-door) of the Way construction, but not to the resultant sound subschema. To a large extent, this finding was to be expected, if we recall that the IMC has been attested with sound-emission verbs since OE times, so that there seems to be no obvious reason why the Way construction should have encroached upon it in that particular function.

6 The following clarifications are in order regarding the information provided in table 9: (i) The discrepancy between the number of tokens (179) indicated in table 9 for CLMET3.03 and the number of tokens (214) in table 4 above, which is based on the same set of sound-emission verbs, is due to the fact that for the comparative study in table 9 I only took into account those cases in which the sound-emission verb was the main verb of its own clause (i.e. I excluded reduced participial clauses). (ii) In the case of CLMET3.03 and CEAL3, the search for the high-frequency verb sing was restricted to the forms sings and sang. In the case of COHA Fiction, the following limitations in the data also have to be noted: the results for crash are based only on the form crashes and the first 100 hits of the form crashed; for roar on the form roars and the first 100 hits of the form roared; for sing on the form sings and the first 100 hits of the form sang; for thunder on the forms thunders, thundered, thundering. It follows from this, therefore, that if my searches had not been restricted as indicated, the token frequency of sound-emission verbs in COHA would probably be much higher than 39.2 per million words. 
The data in table 9 also reveal that the remarkable growth in frequency in the use of sound-emission verbs initiated in the late eighteenth century, which I pointed out in section 4.2.3 above, has continued during the twentieth century, as shown by the evidence from the two AmE corpora. CEAL3 (1851-1920) consists almost solely of fiction texts and is thus basically comparable to COHA Fiction (1980-9) in terms of genre composition, yet the token frequency of the 34 sound-emission verbs investigated here, normalised per million words, has varied from 28.7 in CEAL3 to 39.2 in COHA. The increase in COHA is even more pronounced when compared to nineteenth-century BrE usage, as represented in CLMET3.03 (normalised token frequency of sound-emission verbs per million words: 14.2), but this subcorpus offers a less reliable basis for comparison, because about half of it $(6,308,906$ words) is non-fiction (see table 1 above), which is arguably less prone to being rich in motion descriptions.

In any case, bearing in mind that the English sound verb lexicon consists chiefly of imitative formations (for discussion, see Fanego 2017: 62-3), the growth in frequency of English sound-emission verbs over the past 200 years appears to confirm Jespersen's important observation that 'in all languages the creation and use of echoic and symbolic words seems to have been on the increase in historical times' (1922: 409-11). If that is the case, then this same factor might be responsible, too, for the prominence of sound verbs in the co-occurrence subschema noted in earlier research on the Way construction. In other words, the imitative, echoic character is shared by both the group of sound-emission verbs examined in this section and by many of the sound verbs that denote actions amenable to being performed simultaneously with motion and which, as a consequence, are often employed in the co-occurrence subschema, as happens with manner-of-speaking verbs (babble, gibber, murmur, etc.; Levin 1993: §37.3) or verbs of nonverbal expression (cackle, chuckle, giggle, etc.; Levin 1993: §40.2), among others. Therefore, an aspect worthy of further investigation is whether, as seems likely, these other verb classes have experienced a similar increase in frequency in modern times that might explain their increased use in the co-occurrence subschema of the Way construction.

\section{Summing up}

The historical development of the Way construction has been interpreted as either a constructional change involving grammaticalisation (Israel 1996; Mondorf 2011) or as a change 'that shares a lot with the more commonly analysed processes of grammaticalization involving lexical items' and is thus 'relevant to grammaticalization theory' (Gisborne \& Patten 2011: 100). Evidence of the traditional diagnostics of grammaticalisation can be found in features such as a significant expansion in the semantic domain of the construction (Israel 1996; Perek 2016), increased productivity and extensive analogisation (the range of verbs occurring in the construction has evolved from a few generic verbs to a wide range of verbs coding secondary or metaphorically derived senses), bleaching and decategorialisation of the noun way 
(Mondorf 2011: 408-9), and increasing obligatorification of the directional argument (Israel 1996: 226-7). These various aspects of the Way construction are well known, so, as noted in the introduction, this article has approached its development from a different standpoint, trying to shed light on issues not previously discussed in the literature, such as the precursors of the Way construction from OE times - a period neglected in all previous studies - and, in particular, its interaction with the IMC in the larger inventory of English motion constructions. Some of the main findings relating to these various aspects are summarised in this section.

\subsection{The chronology of the Way construction and its precursors}

As discussed in section 2.1, Israel's influential study (1996) traces the origins of the modern Way construction to a simpler motion construction consisting of a verb of motion followed by a path noun, as in wente his wei (1390); according to Israel, this structure is 'common from at least 1350 on' (1996: 221) and its early instances tend to feature high-frequency motion verbs. Also according to Israel, the means sense of the construction comes in fairly late, 'at the end of the sixteenth century' (Israel 1996: 223), and is then further extended to an increasing number of new verbs.

The above account has remained basically unchallenged in the vast literature on the Way construction, such as Gisborne \& Patten (2011: 96), Mondorf (2011: 408), Traugott \& Trousdale (2013: 80, 84-5) and Barðdal \& Gildea (2015: 8-9), among others. But as was discussed in section 5, the motion construction which Israel identifies as a precursor of the Way construction is attested as far back as OE, that is, considerably earlier than 1350, and seems to have been modelled on a Latin analogue with the noun via 'way'; the exact contribution of this pattern to the English Way construction is an issue that merits further investigation.

Already at the early stage of $\mathrm{OE}$, the range of verbs collocating with a way argument comprised not just general motion verbs, as asserted by Israel, but also, crucially, non-motion verbs of path creation such as OE aredian 'to find', ryman 'to make, clear a way' and (ge)wyrcan 'to make, do', among others (see (13), (14), (15) above). The reflex of OE (ge)wyrcan, PDE work, is still commonly used in the Way construction (see tables 7-8); aredian and ryman went out of use in early ME, but close synonyms like ME finden and maken became available instead and have remained two of the predicates most commonly employed in the Way construction. It can be said, therefore, that since OE times there has existed remarkable semantic continuity between the Way construction and its precursors, a finding which is reminiscent of Hopper's (1991: 28-30) Principle of Persistence in grammaticalisation, according to which when a form undergoes grammaticalisation from a lexical to a grammatical function, 'some traces of its original lexical meanings tend to adhere to it, and details of its lexical history may be reflected in constraints on its grammatical distribution' (1991: 22). 


\subsection{Networking with the IMC}

The connection between the Way construction and the IMC was hinted at by Goldberg (1995: 207) two decades ago and has been explored in this article by examining the historical development of those two constructions in the light of Goldberg's typology (1995: 59-66, 1997) of R-relations, as detailed in section 4.1. Section 4.2 was concerned with the earlier history of the IMC, based on the account in Fanego (2017). Sections 5 and 6, which constitute the core of this research, turned to the analysis of the Way construction, its precursors since OE times and its development from 1700 onwards. The hypothesis was put forward that, once the Way construction had become part of the grammar of English in the form described in section 5, its preferable use would tend to be to code those R-relations which the IMC coded only sparingly (such as means) or with which it was not compatible (such as co-occurrence). The detailed quantitative analysis of British and American English presented in section 6 proved such a hypothesis to be correct: in modern times the Way construction has become specialised in the expression of means (which is its most common use by far from a quantitative point of view, with token frequencies in the range of 90 per cent in the two corpora of Late Modern British and American English examined in this paper) and co-occurrence (which, according to Perek (2016: 8), has now become its most productive subschema). Finally, the analysis of late twentieth-century AmE usage in the Fiction component of COHA reveals that the Way construction is employed to code the resultant-sound subschema only marginally, so that the IMC continues to be the preferred option to express that relation. This finding is hardly surprising if we recall that the sound resulting from a motion is part of the motor pattern of the motion event, and can thus be perceived as intimately related to its manner; and coding manner, as repeatedly noted, has always been one of the central uses of the IMC.

An issue which could not be examined here because of space limitations involves the factors behind the emergence of the co-occurrence subschema. Has this stemmed from the manner thread, as Israel suggests (1996: 225), or rather, as argued by Perek, is it an extension of the means or path-creation sense, 'drawing on the idea that it relates to cases where the enablement of motion is accidental rather than intended' (2016: 18)? What exactly has been the role of sound verbs in the development and growth of that subschema? These are questions that surely deserve further investigation, as I pointed out at the end of section 6 , but which for the time being must be left for future research.

Author's address:

Department of English and German

University of Santiago de Compostela

Facultad de Filología

E-15782 Santiago de Compostela

Spain

teresa.fanego@usc.es 


\section{References}

Barðdal, Jóhanna \& Spike Gildea. 2015. Diachronic Construction Grammar: Epistemological context, basic assumptions and historical implications. In Jóhanna Barðdal, Elena Smirnova, Lotte Sommerer \& Spike Gildea (eds.), Diachronic Construction Grammar, 1-49. Amsterdam: John Benjamins.

Bravo, Bartolomé, Pedro de Salas \& Valeriano Requejo (eds.). 1795 [1590]. Thesaurus hispano-latinus utriusque linguae: verbis et phrasibus abundans. Barcinona: Excudebat Joannes Franciscus Piferrer.

B\&T $=$ Bosworth, Joseph \& T. Northcote Toller. 1898. An Anglo-Saxon dictionary. 1921. Supplement by T. Northcote Toller. 1972. Revised and enlarged addenda by Alistair Campbell. Oxford: Clarendon Press.

Bybee, Joan. 2010. Language, usage and cognition. Cambridge: Cambridge University Press. Clare, P. G. W. (ed.). 2004 [1982]. Oxford Latin dictionary. Oxford: Clarendon Press. Davies, Mark. 2010-. The Corpus of Historical American English: 400 million words, 1810-2009. http://corpus.byu.edu/coha/ (accessed 31 January 2018).

De Smet, Hendrik, Hans-Jürgen Diller \& Jukka Tyrkkö (comps). 2013. The Corpus of Late Modern English Texts, version 3.0. Leuven: KU Leuven.

$D O E=$ Cameron, Angus, Ashley Crandell Amos \& Antonette di Paolo Healey (eds.). 2016. Dictionary of Old English: A to H online. Toronto: Dictionary of Old English Project. www.doe.utoronto.ca/pages/index.html (accessed 28 February 2018).

Fanego, Teresa. 2012. Motion events in English: The emergence and diachrony of manner salience from Old English to Late Modern English. Folia Linguistica Historica 33, 29-85.

Fanego, Teresa. 2017. The trolley rumbled through the tunnel: On the history of the English Intransitive Motion Construction. Folia Linguistica Historica 38, 29-73.

Fillmore, Charles, Paul Kay \& Mary O'Connor. 1988. Regularity and idiomaticity in grammatical constructions: The case of let alone. Language 64(3), 501-38.

Gisborne, Nikolas \& Amanda Patten. 2011. Construction Grammar and grammaticalization. In Heiko Narrog \& Bernd Heine (eds.), The Oxford handbook of grammaticalization, 92-104. Oxford: Oxford University Press.

Goldberg, Adele E. 1995. Constructions: A Construction Grammar approach to argument structure. Chicago: University of Chicago Press.

Goldberg, Adele E. 1997. The relationship between verbs and constructions. In Marjolijn Verspoor, Kee Dong Lee \& Eve Sweetser (eds.), Lexical and syntactical constructions and the construction of meaning. Proceedings of the Bi-annual ICLA Meeting in Albuquerque, July 1995, 383-98. Amsterdam: John Benjamins.

Höglund, Mikko \& Kaj Syrjänen. 2016. Corpus of Early American Literature. ICAME Journal 40, 17-38.

Hopper, Paul J. 1991. On some principles of grammaticization. In Elizabeth Closs Traugott \& Bernd Heine (eds.), Approaches to grammaticalization, vol. I: 17-35. Amsterdam: John Benjamins.

Huber, Judith. 2017. Motion and the English verb: A diachronic study. Oxford: Oxford University Press.

Israel, Michael. 1996. The way constructions grow. In Adele E. Goldberg (ed.), Conceptual structure, discourse and language, 217-30. Stanford, CA: CSLI Publications.

Jackendoff, Ray. 1990. Semantic structures. Cambridge, MA: MIT Press.

Jespersen, Otto. 1922. Language: Its nature, development and origin. London: George Allen \& Unwin.

Levin, Beth. 1993. English verb classes and alternations. A preliminary investigation. Chicago: University of Chicago Press. 
$M E D=$ Kurath, Hans, Sherman M. Kuhn \& Robert E. Lewis (eds.). 1952-2001. Middle English dictionary. Ann Arbor, MI: University of Michigan Press.

http://quod.lib.umich.edu/m/med/ (accessed 28 February 2018).

Michaelis, Laura. 2003. Headless constructions and coercion by construction. In Elaine J. Francis \& Laura Michaelis (eds.), Form-function incongruity and the architecture of grammar, 259-310. Stanford, CA: CSLI Publications.

Mitchell, Bruce. 1985. Old English syntax. Oxford: Clarendon Press.

Mondorf, Britta. 2011. Variation and change in English resultative constructions. Language Variation and Change 22(3), 397-421.

$O E D=$ Oxford English dictionary online. www.oed.com (accessed 28 February 2018).

Ogura, Michiko. 2002. Verbs of motion in medieval English. Cambridge: D. S. Brewer.

Olofsson, Joel. 2014. Argument structure constructions and syntactic productivity. The case of Swedish motion constructions. Constructions 1, 1-17.

van Peene, J. H. 1818. Recueil ou collection de tous les verbes latins, avec des locutions appropriées à chaque verbe. Gand: Veuve Stéven.

Perek, Florent. 2016. Recent change in the productivity and schematicity of the way construction: A distributional semantic analysis. Corpus Linguistics and Linguistic Theory. https://doi.org/10.1515/cllt-2016-0014

Rohde, Ada. 2001. Analyzing Path: The interplay of verbs, prepositions and constructional semantics. PhD dissertation, Rice University.

Slobin, Dan I. 2004. The many ways to search for a frog: Linguistic typology and the expression of motion events. In Sven Strömqvist \& Ludo Verhoeven (eds.), Relating events in narrative, vol. II: Typological and contextual perspectives, 219-57. Mahwah, NJ: Lawrence Erlbaum Associates.

Talmy, Leonard. 1985. Force dynamics in language and thought. Chicago Linguistic Society (CLS) 21(1), 293-337.

Talmy, Leonard. 2000. Toward a cognitive semantics, vol. I: Concept structuring systems; vol. II: Typology and process in concept structuring. Cambridge, MA: MIT Press.

Traugott, Elizabeth Closs \& Graeme Trousdale. 2013. Constructionalization and constructional changes. Oxford: Oxford University Press. 